\section{Conservation of wild orchids in Sri Krishnadevaraya University Botanic Garden, Anantapur, Andhra Pradesh, India}

\author{
K. Prasad ${ }^{1}$, B. Sadasivaiah ${ }^{2}$, S. Khadar Basha ${ }^{3}$, \\ M.V. Suresh Babu ${ }^{4}$, V. Sreenivasa Rao ${ }^{5}$, \\ P. Priyadarshini ${ }^{6}$, D. Veeranjaneyulu ${ }^{7} \&$ B. Ravi \\ Prasad Rao ${ }^{8}$
}

1,2,3,4,5,6,7,8 Biodiversity Conservation Division, Department of Botany, Sri Krishnadevaraya University, Anantapur, Andhra Pradesh 515003, India

Email: ${ }^{1}$ prasad.orchids@gmail.com, ${ }^{2}$ chum_sada@rediffmail.com, ${ }^{3}$ khadar_ced@yahoo.co.in, ${ }^{4}$ mvs_ced@rediffmail.com

${ }^{5}$ vendrapati@yahoo.com, ${ }^{6}$ priya_ced@rediffmail.com,

${ }^{7}$ hanveerobu@gmail.com, ${ }^{8}$ biodiversityravi@gmail.com (corresponding author)

Sri Krishnadevaraya University Botanic Garden was established in 1975 and is being maintained by the Department of Botany. The garden extends over 20000sq.m within the university campus and located $10 \mathrm{~km}$ away from Anantapur City. The garden is situated at $14^{0} 36^{\prime} 43.67^{\prime \prime} \mathrm{N}$ and $77^{0} 38^{\prime} 42.34{ }^{\prime} \mathrm{E}$ at an altitude of $377 \mathrm{~m}$. The area receives moderate annual rainfall of about $538 \mathrm{~mm}$ and experiences a mean daily maximum temperature of $28.7^{\circ} \mathrm{C}$ (in summer season it is $38-40{ }^{\circ} \mathrm{C}$ ). The garden currently harbours about

Date of publication (online): 26 July 2012

Date of publication (print): 26 July 2012

ISSN $0974-7907$ (online) | 0974-7893 (print)

Editor: K. Ravikumar

\section{Manuscript details:}

Ms \# 02928

Received 27 August 2011

Final received 06 June 2012

Finally accepted 28 June 2012

Citation: Prasad, K., B. Sadasivaiah, S.K. Basha, M.V.S. Babu, V.S. Rao, P. Priyadarshini, D. Veeranjaneyulu \& B.R.P. Rao (2012). Conservation of wild orchids in Sri Krishnadevaraya University Botanic Garden, Anantapur, Andhra Pradesh, India. Journal of Threatened Taxa 4(7): 2705-2708.

Copyright: ( ) K. Prasad, B. Sadasivaiah, S. Khadar Basha, M.V. Suresh Babu, V. Sreenivasa Rao, P. Priyadarshini, D. Veeranjaneyulu \& B. Rav Prasad Rao 2012. Creative Commons Attribution 3.0 Unported License. JoTT allows unrestricted use of this article in any medium for non-profit purposes, reproduction and distribution by providing adequate credit to the authors and the source of publication.

Acknowledgements: The authors are grateful to the Department of Biotechnology (BT/PR6603/NDB/ 51/089/2005), New Delhi for financial assistance. Thanks are due to Andhra Pradesh Forest Department officials for their help in field work.

\section{OPEN ACCESS | FREE DOWNLOAD}

300 indigenous and exotic taxa including endemics. Orchids collected from different parts

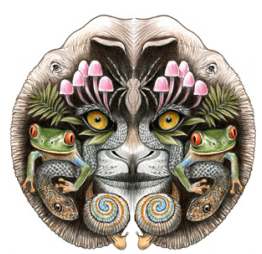
of the Eastern Ghats are being maintained by the research group of Biodiversity Conservation Division (BCD) of the Department of Botany.

Orchids are one of the largest groups in the plant kingdom comprising 22,075 species (APG 2009), of which 1331 taxa are found in India (Misra 2007). In the state of Andhra Pradesh, 77 species have so far been reported to occur in different habitats (Raju et al. 2008), however, most of them are encountered in the forests of the Eastern Ghats. Orchids are experiencing major threats in terms of habitat destruction due to over grazing, forest fires, encroachment of forest land for agriculture and plantation purposes. This situation in Andhra Pradesh prompted the ex situ maintenance of selected orchid species in the botanic garden.

At present, 32 orchid species collected from different parts of the Eastern Ghats of Andhra Pradesh are being maintained in the botanic garden green house and the epiphytic ones are on trees within the garden premises (Table 1). Of the 32 species, 13 are epiphytic and 19 are terrestrial ones. The terrestrial orchids are potted by using red soil mixed with pieces of brick, charcoal and manure (3:2:2:3). The epiphytic orchids are grown in pots using bricks, charcoal, coir pieces with fresh cattle dung (3:3:2:2) and are tied on the trunk of living trees with the help of a gunny-bag fill of the above materials (Image 1). Watering of the plants is done every day in summer and every 2-3 days in a week during the rainy season.

Of the 32 orchid species, five are endemic to India (Ahmedullah et al. 1986) and they are: Cirrhopetalum neilgherrense, Habenaria longicornu, $H$. panigrahiana, $H$. rariflora and $H$. roxburghii; Cirrhopetalum neilgherrense is categorised as Vulnerable (Nayar \& Sastry 2000); Eulophia graminea is relocated after eight decades in Andhra Pradesh (Sadasivaiah et al. 2010); one species, Eulophia flava is a new distributional record for the Eastern Ghats (Rao et al. 2010); Geodorum recurvum is a new record for the southern Eastern Ghats (Prasad \& Rao 2010); Habenaria panigrahiana, Liparis nervosa and $L$. paradoxa are new distributional records for Andhra Pradesh (Sadasivaiah et al. 2009; Prasad et al. 
Table 1. List of orchids conserved in Sri Krishnadevaraya University Botanic Garden

\begin{tabular}{|c|c|c|c|c|c|}
\hline & Binomial & Habit & $\begin{array}{c}\text { Distribution in Andhra } \\
\text { Pradesh }\end{array}$ & $\begin{array}{l}\text { Endemic/ } \\
\text { Threat status }\end{array}$ & $\begin{array}{l}\text { Medicinal } \\
\text { value }\end{array}$ \\
\hline 1 & Acampe praemorsa (Roxb.) Blatter \& McCann & E & $\mathrm{Ch}, \mathrm{Eg}, \mathrm{Ku}, \mathrm{Pr}, \mathrm{Sr}, \mathrm{Vi} \& \mathrm{Wg}$ & & + \\
\hline 2 & Aerides odorata Lour. & E & Eg, Vi \& Wg & & \\
\hline 3 & Cirrhopetalum neilgherrense Wight & E & $\mathrm{Ch}$ & PI-VU & + \\
\hline 4 & Cymbidium aloifolium (L.) Sw. & $\mathrm{E}$ & $\mathrm{Ch}, \mathrm{Eg}, \mathrm{Sr}, \mathrm{Ne}, \mathrm{Vi}, \mathrm{Wg} \& \mathrm{Vj}$ & & + \\
\hline 5 & Dendrobium aphyllum (Roxb.) C.E.C. Fischer & $\mathrm{E}$ & $\mathrm{Eg}, \mathrm{Sr} \& \mathrm{Vi}$ & & \\
\hline 6 & Dendrobium macrostachyum Lindley & $\mathrm{E}$ & $\mathrm{Ch}, \mathrm{Ku} \& \mathrm{Vi}$ & & + \\
\hline 7 & Eulophia epidendraea (Koenig ex Retz.) C.E.C. Fischer & $\mathrm{T}$ & $\mathrm{Ch}, \mathrm{Ka}, \mathrm{Ne}, \mathrm{Sr} \& \mathrm{Vi}$ & & + \\
\hline 8 & Eulophia flava (Lindley) Hook. f. & $\mathrm{T}$ & Ch \& Ka & & \\
\hline 9 & Eulophia graminea Lindley & $\mathrm{T}$ & $\mathrm{Ch}, \mathrm{Ka}, \mathrm{Ma} \& \mathrm{Ne}$ & & \\
\hline 10 & Eulophia explanta Lindley & $T$ & $\mathrm{Eg} \& \mathrm{Vi}$ & & \\
\hline 11 & Eulophia sp. & $\mathrm{T}$ & $\operatorname{Pr}$ & & \\
\hline 12 & Geodorum densiflorum (Lam.) Schltr. & $\mathrm{T}$ & Common & & + \\
\hline 13 & Geodorum recurvum (Roxb.) Alston & $\mathrm{T}$ & $\mathrm{Eg}, \mathrm{Ku}, \mathrm{Ma}, \operatorname{Pr} \& \mathrm{Vi}$ & & \\
\hline 14 & Goodyera procera (Ker-Gawler) Hook. & $T$ & $\mathrm{Ch}, \mathrm{Ka} \& \mathrm{Vi}$ & & \\
\hline 15 & Habenaria longicornu Lindley & $T$ & $\mathrm{Ch}$ & $\mathrm{PI}$ & + \\
\hline 16 & Habenaria panigrahiana S. Misra & $T$ & $\mathrm{Ch}, \mathrm{Eg} \& \mathrm{Ku}$ & $\mathrm{PI}$ & \\
\hline 17 & Habenaria rariflora A.Rich & $\mathrm{T}$ & $\mathrm{Ch}$ & SI & \\
\hline 18 & Habenaria roxburghii $\mathrm{R}$. Br. & $\mathrm{T}$ & $\mathrm{Ad}, \mathrm{Ku}, \mathrm{Me}, \mathrm{Ne}, \mathrm{Ni} \& \mathrm{Vj}$ & IND & + \\
\hline 19 & Liparis deflexa Hook. f. & $T$ & $\mathrm{Eg} \& \mathrm{Ku}$ & & \\
\hline 20 & Liparis nervosa (Thunb.) Lindley & $T$ & Ch \& Vi & & \\
\hline 21 & Liparis paradoxa (Lindley) Reichb. f. & $\mathrm{T}$ & $\mathrm{Ch} \& \mathrm{Ku}$ & & \\
\hline 22 & Luisia trichorhiza (Hook.) Blume & E & $\mathrm{Eg}, \mathrm{Ku} \& \mathrm{Vi}$ & & + \\
\hline 23 & Nervilia aragoana Gaudich. & $\mathrm{T}$ & Eg, Kh, Ku, Vi \&Vj & & + \\
\hline 24 & Nervilia crociformis (Zoll. \& Moritzi) Seidenf. & $\mathrm{T}$ & $\mathrm{Eg} \& \mathrm{Vi}$ & & \\
\hline 25 & Oberonia ensiformis (Sm.) Lindley & $\mathrm{E}$ & $\mathrm{Eg}, \mathrm{Sr}, \mathrm{Vi} \& \mathrm{Vj}$ & & \\
\hline 26 & Oberonia mucronata (D.Don) Ormer. \& Seidenf. & $\mathrm{E}$ & $\mathrm{Sr}, \mathrm{Vi} \& \mathrm{Vj}$ & & \\
\hline 27 & Polystachya concreta (Jacq.) Garay \& Sweet & $\mathrm{E}$ & $\mathrm{Vi}$ & & \\
\hline 28 & Rhynchostylis retusa (L.) Blume & $\mathrm{E}$ & $\mathrm{Eg}, \mathrm{Sr} \& \mathrm{Vi}$ & & + \\
\hline 29 & Seidenfia versicolor (Lindl.) Marg . \& Szlach & $\mathrm{T}$ & $\mathrm{Ch}, \mathrm{Eg}, \mathrm{Sr} \& \mathrm{Vi}$ & & + \\
\hline 30 & Vanda tessellata (Roxb.) Hook. ex G. Don & $\mathrm{E}$ & Common & & + \\
\hline 31 & Vanda testacea (Lindley) Reichb. f. & E & $\begin{array}{l}\text { Ch, Eg, Ku, Ma, Ne, Sr, Vi } \\
\& \text { Vj }\end{array}$ & & + \\
\hline 32 & Vanilla walkeriae Wight & v & $\mathrm{Eg} \& \mathrm{Ch}$ & & \\
\hline
\end{tabular}

Habit: (E - Epiphyte, T - Terrestrial, V - Vine); Distribution in Andhra Pradesh: (Ad - Adilabad, Ch - Chittoor, Eg - East Godavari, Kh - Khammam, Ka - Kadapa, Ku - Kurnool, Ma - Mahaboobnagar, Me - Medak, Ne - Nellore, Ni - Nizamabad, Pr - Prakasam, Sr - Srikakulam, Vi - Visakhapatnam, Vj Vijayanagaram, Wg - West Godavari); Endemics/Threat status: (IND - India, PI - Peninsular India, SI - South India, VU - Vulnerable).

2010). Of the 32 species, 14 species are reported with medicinal values (Reddy et al. 2005; Raju et al. 2008). All the 32 species are listed in Table 1 with their habit, distribution pattern in Andhra Pradesh, endemic status and medicinal value.

\section{REFERENCES}

Ahmedullah, M. \& M.P. Nayar (1986). Endemic Plants of the Indian Region-Vol. 1. Botanical Survey of India, New Delhi, 261pp.

APG (2009). An update of the Angiosperm Phylogeny Group classification for the orders and families of flowering plants: APG III. Bot. Journal of Linnean Society 161: 105-121.

Misra, S. (2007). Orchids of India - A Glimpse. Bishen Singh 

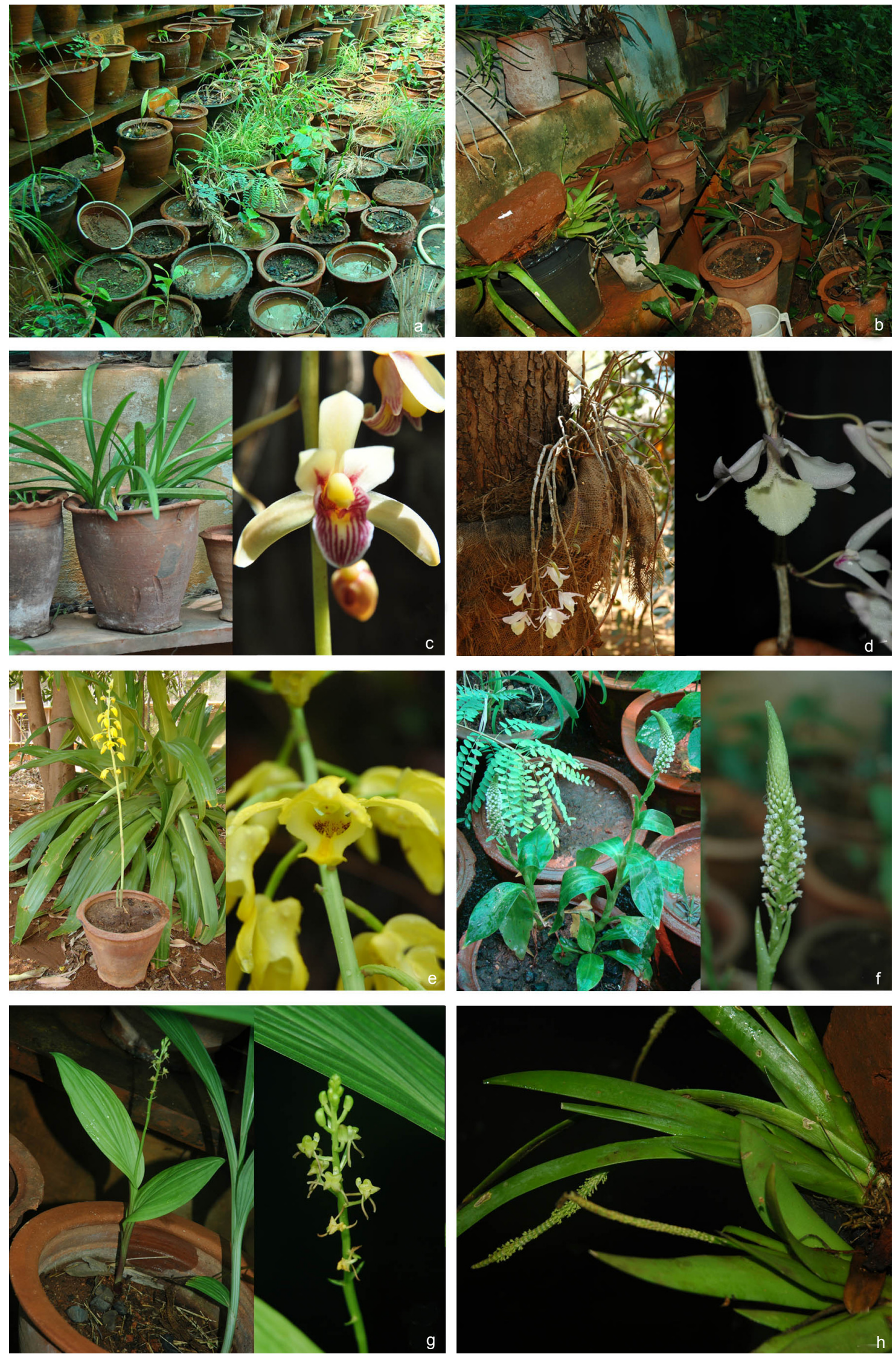

Image 1. a \& b - Interior of the Garden; c - Cymbidium aloifolium; d - Dendrobium aphyllum; e - Eulophia flava; $\mathrm{f}$ - Goodyera procera; $\mathrm{g}$ - Liparis paradoxa; $\mathrm{h}$ - Oberonia ensiformis. (C) BCD Group 
Mahendra Pal Sing, Dehra Dun, India, 390pp.

Nayar, M.P. \& A.R.K. Sastry (2000). Red Data Book of Indian Plants-Vol. 1. Botanical Survey of India, Calcutta, $367 \mathrm{pp}$.

Prasad, K., M.V.S. Babu, B. Sadasivaiah \& B.R.P. Rao (2010). Two species of Liparis L.C. Richard (Orchidaceae), new distributional records to Andhra Pradesh, India. The Journal of the Economic Taxonomic Botany 34(3): 514 516.

Prasad, K. \& B.R.P. Rao (2010). Geodorum recurvum, new distribution record to southern Eastern Ghats of India Indian Journal of Forestry 33(1): 119-121.

Raju, V.S., C.S. Reddy, K.N. Reddy, K.S. Rao \& B. Bahadur (2008). Orchid Wealth of Andhra Pradesh. Proceedings of Andhra Pradesh Akademi of Sciences 12(1\&2): 180-192.

Rao, B.R.P., B. Sadasivaiah, K. Prasad, S.K. Basha, A.
Miria, A.B. Khan \& M.V.S. Babu (2010). Eulophia flava (Lindl.) Hook.f. (Orchidaceae), in Eastern Ghats, India. Indian Journal of Forestry 33(3): 403-404.

Reddy, K.N., G.V. Subbaraju, C.S. Reddy \& V.S. Raju (2005). Ethnobotany of certain orchids of Eastern Ghats of Andhra Pradesh. EPTRI-ENVIS Newsletter 11(3): 5-9.

Sadasivaiah, B., K. Prasad, V.S. Rao \& B.R.P. Rao (2009). Habenaria panigrahiana S. Misra - a new distributional record to Andhra Pradesh, India. The Journal of the Swamy Botanical Club 26: 1-2.

Sadasivaiah, B., K. Prasad, S.K. Basha, M.V.S. Babu, V.S. Rao \& B.R.P. Rao (2010). Eulophia graminea Lindl., E. ochreata Lindl. and Habenaria barbata Wight ex Hook.f. - Relocated in Andhra Pradesh after Eight Decades. Indian Journal of Forestry 33(2): 211-214. 